\title{
Historical highlights on cancer invading the portal vein
}

\author{
Wilson I. B. Onuigbo* \\ Department of Pathology, Medical Foundation and Clinic, Nigeria
}

\begin{abstract}
Introduction

There is the Standard Textbook on "The Spread of Tumours in the Human Body" published by Willis [1]. He usually takes the trouble to supply historical antecedent. This is a practice favored by Macfarlane Burnet [2]. In particular, as regards the invasion of the portal vein by cancer, 1866 was the earliest date. Therefore, it is of interest that this particular 1867 was the one cited by William Legg [3] in 1876. This was when he himself provided a copious account of this phenomenon. It deserves documentation evidence.
\end{abstract}

In the weighty book on the spread of cancer in the human body, Willis went only as far back as to 1876 concerning knowledge of how hepatic cancer often shows gross invasion of the portal vein and its branches. An old paper also cited the above 1876 work. Therefore, let me highlight the associated data actually. Such documentation is recommended concerning present truths.

\section{Historical abridgements}

Sussanah K -, aged 78, was admitted into St. Bartholomew's Hospital, under the care of Dr. Brunton, on August 10th, 1875. She continued to vomit, and no relief to this symptom could be secured. She died on October 28th at nine in the morning. The liver itself weighs $2500 \mathrm{grm}$. On the surface are many nodules, about twenty, of size varying from a mustard seed to a small apple. Their outline is rounded, color whitish, and some are distinctly umbilicated. On cutting into the liver, however, the nodules are far more numerous within. They are round, white, rather firm, and many show small hæmorrhages. The liver substance between the nodules is natural, save that the centre of the lobule seems darker than natural. The hepatic veins are natural. On dissecting the portal vein within the liver, one of the first divisions of the right branch is found filled by several polypoid bodies. They are smooth and club-shaped at the end, where they project into the free cavity of the vein; above they become slightly adherent to the vein-wall, which appears perfectly natural. They send prolongations up branches of the portal vein above them, where after travelling up some short distance they again end in a bulbous projection. Their origin, however, appears to be in each case in one of the large nodules of the right lobe, to which they are attached by long and narrow pedicles.

The polypoid bodies from the portal vein were examined by means of Hartnack's microscope the same day. The field was flooded with oval nuclei; many large cells, containing abundance of fat, and with these nuclei in them, were likewise seen. The nuclei often contained two or three nucleoli. Acetic acid brought out the nuclei well leaving the fat drops undisturbed.

The polypi in the portal vein showed a delicate network supporting cells. The walls of the alveoli were very thin, while the meshes themselves were wide and rounded. The walls were formed of an almost homogeneous material, scarcely fibrous, and showing very few nuclei. The cells were all contained in the meshes of the network: they were somewhat tightly packed, inclining to be polyhedral in shape, containing a large nucleus about the size of a white corpuscle; sometimes two nuclei were present in one cell. The contents of the cells were highly fatty and granular. Precisely the same appearances were found in the tumours in the liver.

A case like this must, I think, be clearly separated from those which have been recorded as cancer of the portal vein. In such cases the portal vein, both within and without the liver. Is reported o be filled with a thick, creamy matter, which is assumed to be of a cancerous nature. I do not think there is any good evidence in these cases that this matter is really cancer. Of course, before the microscope came into such general use as at present such appearances in the portal vein were at once set down as cancer. But even in those more lately published, such as a most carefully worked-up case of Spaeth, the histological evidence of a cancerous growth in the vein seems weak. It is based solely on the presence of large cells in the material filling the vein.

In reference to these polypi, I have only further to add that I scarcely think they are so rare as the few cases on record would lead us to believe. The branches of the portal vein are but rarely dissected out, and unless this be done it are, of course, unlikely that such would be noticed.

\section{Discussion}

It is of interest to compare these copious microscopical appearances with a modern picture painted briefly thus [4]:

Microscopically, HCC is usually made up of tumor cells that are similar to normal hepatocytes, but with abundant eosinophilic cytoplasm and prominent nucleoli. The tumor cells are cohesive and grow as so-called trabeculae, one to several cells thick, lined by endothelial cells that separate sinusoidal blood from the tumor cells.

A Japanese group [5] was brief as follows: “At autopsy, the

Correspondence to: Wilson I. B. Onuigbo, Department of Pathology, Medical Foundation and Clinic, 8 Nsukka Lane, Enugu 400001, Nigeria, E-mail: wilson. onuigbo@gmail.com

Key words: cancer, spread, portal vein, history

Received: November 21, 2016; Accepted: December 14, 2016; Published: December 19, 2016 
intrahepatic portal branches are completely filled by growing tumor thrombi or tumor casts." Another Japanese group was also brief thus: "tumor thrombi are frequently found at autopsy in the portal vein branches" [6].

Incidentally, portal venous invasion may be the most significant risk factor as regards postoperative recurrence of liver cancer [7]. Noteworthy, also is such a maneuver as angiographic demonstration of tumor cast growing in a large branch of the portal vein [6]. In addition, it was observed postoperatively in colorectal cancer that "a better prognosis may be expected when the tumor can be completely resected en-bloc by anatomic hepatechtomy" [8].

\section{References}

1. Willis RA (1973) The spread of tumours in the human body. London: Butterworths: 91.

2. Burnet FM (1977) Morphogenesis and cancer. Med J Aust 1: 5-9.[Crossref]
3. Legg JW (1878) Melanotic sarcoma of the eyeball; secondary growths in the organs of the chest and belly, particularly in the liver. Trans Path Soc Lond 29: 225-229.

4. Edmondson HA, Peters RL (1983) Tumors of the liver: pathologic features. Semin Roentgenol 18: 75-83.[Crossref]

5. Okuda K, Musha H, Yoshida T, Kanda Y, Yamazaki T (1975) Demonstration of growing casts of hepatocellular carcinoma in the portal vein by celiac angiography: The thread and streaks sign. Radiology 117: 303-309.[Crossref]

6. Okuda K, Musha H, Yamasaki T, Jinnouchi S, Nagasaki Y, et al. (1977) Angiographic demonstration of intrahepatic arterio-portal anastomoses in hepatocellular carcinoma. Radiology 122: 53-58. [Crossref]

7. Choi KK, Kim SH, Choi SB, Lim JH, Choi GH, et al. (2011) Portal venous invasion. The single most independent risk factor for immediate postoperative recurrence of hepatocellular carcinoma. J Gastroenterol Hepatol, 26: 1646-1651. [Crossref]

8. Matsumoto J, Kojima T, Hiraguchi E, Abe M (2009) Portal vein tumor thrombus from colorectal cancer with no definite metastatic nodules in liver parenchyma. $J$ HepatoBil-Pancr Sci 16: 688-691.[Crossref]

Copyright: $\ 2016$ Onuigbo WIB. This is an open-access article distributed under the terms of the Creative Commons Attribution License, which permits unrestricted use, distribution, and reproduction in any medium, provided the original author and source are credited. 